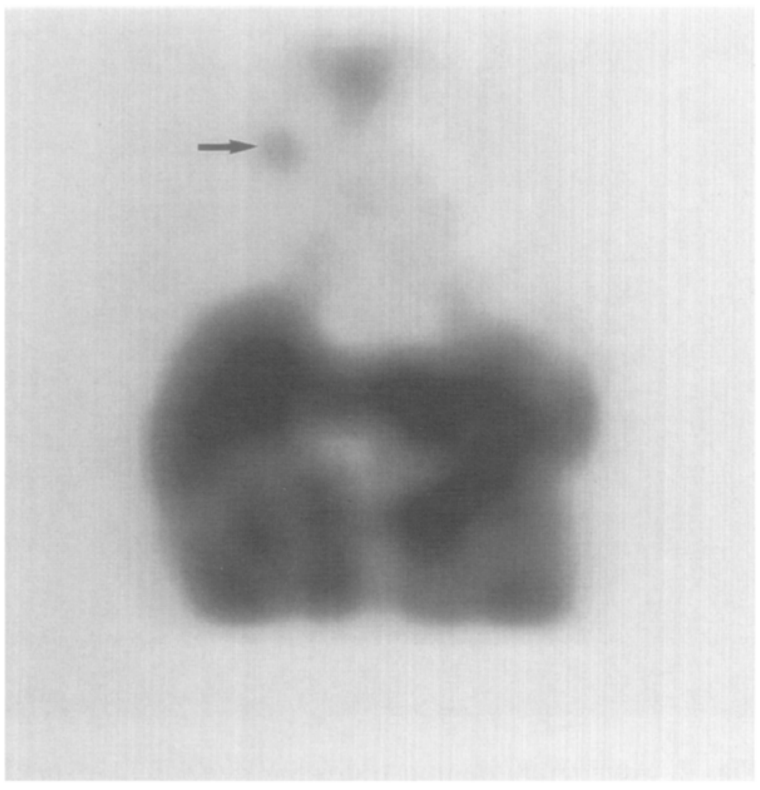

Fig. 2. Somatostatin receptor scintigraphy demonstrates increased uptake in the right upper lobe (arrow) corresponding to the nodule seen on computed tomographic scan.

receptor scans. ${ }^{5}$ False positive lung scans have also been noted to result from increased hilar uptake after an upper respiratory tract infection, external beam irradiation, bleomycin administration, or surgical treatment. ${ }^{5}$ However, if interpreted in an appropriate clinical setting, somatostatin receptor scintigraphy may provide an accurate, noninvasive technique for the characterization of indeterminate pulmonary nodules as hormonally active and should be considered in the diagnostic evaluation of the patient with Cushing's syndrome.

\section{REFERENCES}

1. Orth DN. Ectopic hormone production. In: Felig P, Baxter JD, Broadus AE, Frohman La, editors: Endocrinology and metabolism. 2nd ed. New York: McGraw-Hill, 1987:1692-735.

2. Richardson RI, Greco FA, Oldham RK, et al. Tumor products and potential markers in small cell lung cancer. Semin Oncol 1978;5:253-8.

3. Reubi JC, Kvols LK, Waser B, et al. Detection of somatostatin receptors in surgical and percutaneous needle biopsy samples of carcinoids and islet cell carcinomas. Cancer Res 1990;50: $5960-5$.

4. de Herder WW, Krenning EP, Malchoff CD, et al. Somatostatin receptor scintigraphy: its value in tumor localization in patients with Cushing's syndrome caused by ectopic corticotropin or corticotropin-releasing hormone stimulation. Am J Med 1994;96:305-12.

5. Krenning EP, Kwekkeboom DJ, Baker WH, et al. Somatostatin receptor scintigraphy with $\left[{ }^{111}\right.$ In-DTPA-D-Phe $\left.{ }^{1}\right]$ - and $\left[{ }^{123} \mathrm{I}-\right.$ tyr $^{3}$ ]-octreotide: The Rotterdam experience with more than 1000 patients. Eur J Nucl Med 1993;20:716-31.

\title{
PULSATING MASS AT THE STERNUM: A PRIMARY CARCINOMA OF ECTOPIC MEDIASTINAL THYROID
}

Juhani Sand, MD, ${ }^{a}$ Erkki Pehkonen, MD, ${ }^{a}$ Jorma Mattila, MD, ${ }^{\mathrm{b}}$ Seppo Seppänen, MD, ${ }^{\mathrm{c}}$ and Jorma Salmi, MD, Tampere, Finland

During embryogenesis the descent of the thymus, thyroid, and parathyroid glands may be disturbed, leading to various possibilities for anomalous locations of each gland. One of the aberrant locations of the ectopic thyroid is the mediastinum. Rarely, a mass in the anterior upper mediastinum

From the Departments of Thoracic and General Surgery, ${ }^{a} \mathrm{~Pa}-$ thology, ${ }^{\mathrm{b}}$ Radiology, ${ }^{\mathrm{c}}$ and Medicine, ${ }^{\mathrm{d}}$ Tampere University Hospital, Tampere Medical School, Tampere University, Tampere, Finland.

Received for publication Dec. 8, 1995; accepted for publication Dec. 21, 1995.

Address for reprints: Juhani Sand, MD, Department of Surgery, Tampere University Hospital, FIN-33521 Tampere, Finland.

J Thorac Cardiovase Surg 1996;112:833-5

Copyright (C) 1996 by Mosby-Year Book, Inc. $0022-5223 / 96 \$ 5.00+0 \quad \mathbf{1 2 / 5 4 / 7 1 4 5 0}$ may be a primary mediastinal goiter. ${ }^{1}$ Even more rare is primary carcinoma in the ectopic mediastinal thyroid. ${ }^{2}$

Case report. A 62-year-old woman was referred to Tampere University Hospital in 1993 because of a palpable pulsating tumor in the sternum. The patient was free of symptoms and in good general condition. Eight years earlier she had been operated on for a benign follicular goiter and 6 years earlier she had had a benign gastric ulcer.

Clinical examination revealed a mass in the middle portion of the sternum with a clear pulsation. Palpation of the neck demonstrated a pretracheal thyroid of normal size without abnormal nodules. Doppler examination demonstrated a strong whizzing sound in the tumor during systole. The chest $\mathrm{x}$-ray film showed a weak soft tissue expansion behind the sternum (Fig. 1). A strongly vascularized tumor or arteriovenous fistula was suspected and angiography was performed. The angiogram revealed a vascular tumor behind the sternum with vascular supply from both internal thoracic arteries (Fig. 2). The vascular 


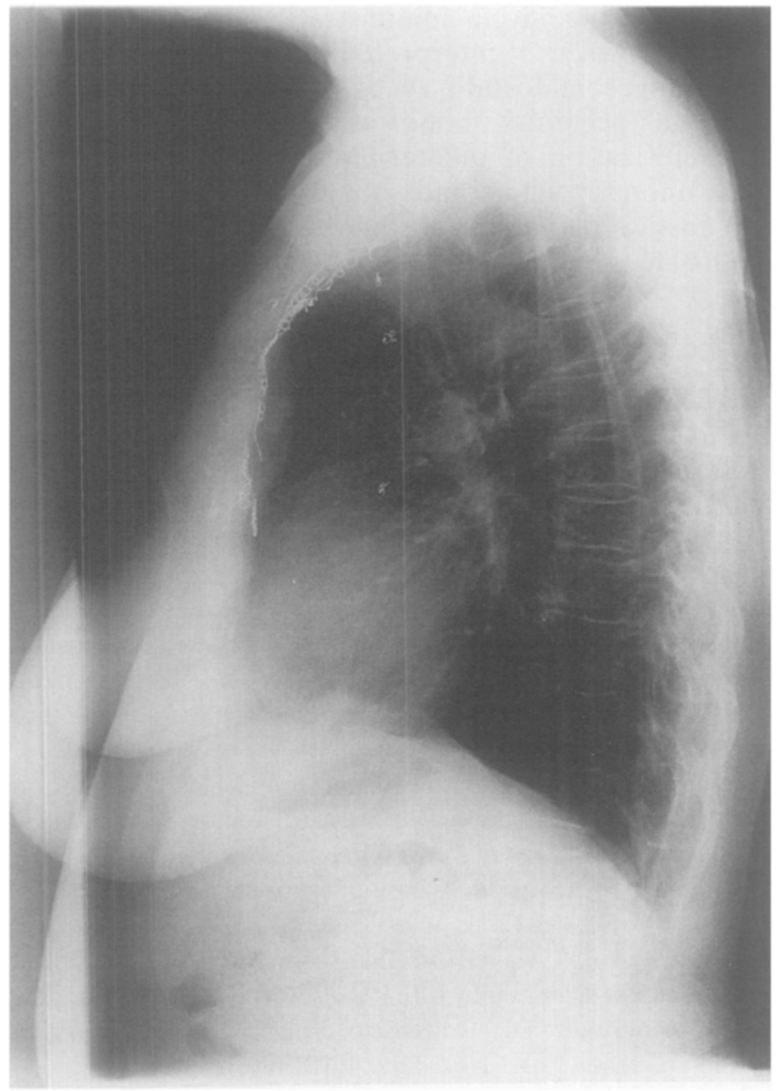

Fig. 1. Chest x-ray film demonstrates a weak soft tissue expansion, which was found to be an ectopic thyroid carcinoma, behind the sternum. Note the coils after embolization.

supply of the tumor was embolized with platinum coils. The size of the tumor decreased slightly and the pulsation disappeared. The tumor was believed to be possible hemangioma and an operation was considered. In the interval before the operation, the pulsation reappeared and the embolization was repeated together with direct percutaneous injection of $5 \mathrm{ml}$ of absolute ethanol. Before the sclerotherapy, a sample was taken by fine needle aspiration, which revealed atypical cells with a mild suggestion of malignancy.

The operation revealed a 5 by 5 by $3 \mathrm{~cm}$ tumor in the middle part of the sternum and behind the sternum. The sternum was divided by the tumor into two separate pieces, but the pericardium was not invaded. The tumor was excised en bloc with a $1 \mathrm{~cm}$ margin, and the defect in the anterior chest wall was reconstructed with a flap of pectoralis muscle.

Final histologic study showed a pure follicular growth pattern, but locally there were slightly enlarged nuclei, crowded and overlapping and having a groundglass appearance, some of them with nuclear grooves. All of these features are consistent with papillary thyroid carcinoma. The tumor was considered to be a possible metastasis from a thyroid carcinoma. The histologic specimen of the previous thyroid tumor was reevaluated, but the pathologic diagnosis remained benign follicular adenomatous hyperplasia.

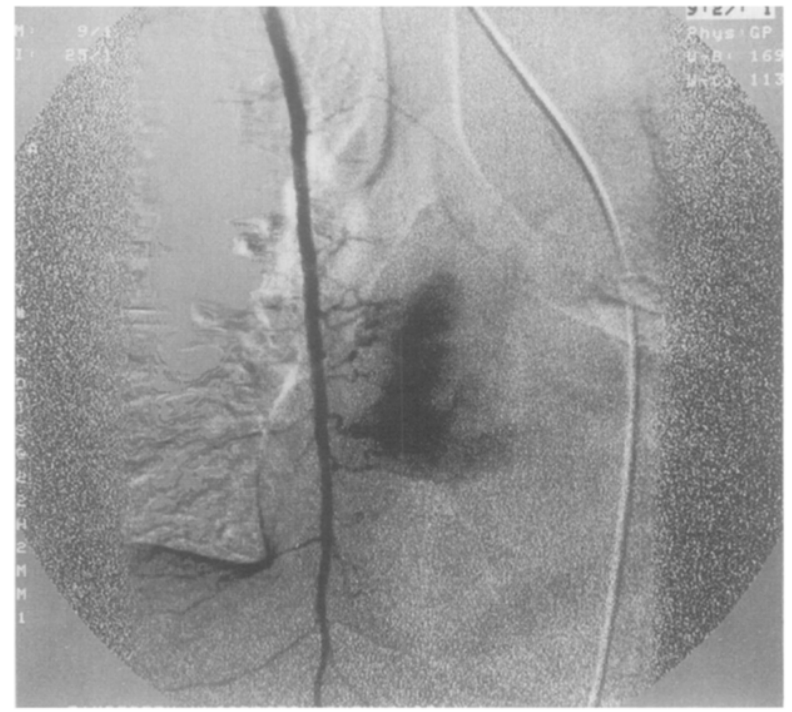

Fig. 2. Angiogram demonstrates the rich vascular supply of the tumor from internal thoracic arteries.

Total thyroidectomy was performed. Preoperative ultrasonography did not demonstrate any thyroid disease. There were no diseased nodules in the thyroid or in the nodular regions between the carotid vessels. There were no connections from the thyroid isthmus or lower poles to the upper part of the mediastinum. The whole thyroid gland weighed only $12 \mathrm{gm}$. Final histologic study did not demonstrate any neoplastic signs. The patient has recovered uneventfully from both operations. The postoperative scintiscan with radiolabeled iodine demonstrated minor accumulation of activity in the lower part of the mediastinum, but not in the neck.

Discussion. During embryogenesis, the thyroid gland develops together with the parathyroid and thymus from the primordial pharynx and its pouches. According to the time of the disturbance during embryogenesis, ectopic thyroid may develop at various sites from the base of the tongue to the thyroglossal duct. ${ }^{3}$ The genesis of the thyroid gland also is related to the genesis of the heart. If contact with the heart is missed, a lingual thyroid may develop. If the contact is too close, intracardiac thyroid ectopy may develop. ${ }^{4}$ The most common site for ectopic thyroid is the tongue, with thyroid tissue being microscopically detected in up to $10 \%$ of autopsies.

Mediastinal goiter is not uncommon, comprising about $15 \%$ of all goiters. However, in more than $99 \%$ of cases the mediastinal goiter is secondary, receiving its blood supply from thyroid arteries. ${ }^{1}$ A primary mediastinal thyroid, as in. the present case, receives its blood supply from thoracic vessels, necessitating a thoracic approach during the operation. Ectopic mediastinal thyroid tissue is usually not alarming, but especially after pretracheal thyroidectomy it may become symptomatic. ${ }^{5}$ The current patient had previously undergone thyroid resection, and that might have stimulated the growth of the ectopic mediastinal thyroid. However, she was free of symptoms, whereas more than half of patients with mediastinal goiters have symptoms. 
In the present patient the mediastinal mass was a thyroid carcinoma. In patients with normal pretracheal thyroid it is difficult to distinguish with certainty between metastasis and primary ectopic carcinoma. However, careful examination of the pretracheal thyroidectomy specimen, in addition to angiographic finding, excluded the possibility of metastasis in the mediastinum. Instead, the tumor was a primary carcinoma of ectopic mediastinal thyroid. Primary ectopic thyroid carcinoma has previously been observed rarely. ${ }^{2}$

Ectopic mediastinal thyroid and even primary thyroid carcinoma should be kept in mind when examining a patient with a mass in the upper anterior part of the mediastinum, even if the patient has a normal pretracheal thyroid gland.

\section{REFERENCES}

1. Spinner RJ, Moore KL, Gottfried, Lowe JE, Sabiston DC. Thoracic intrathymic thyroid. Ann Surg 1994;220:91-6.

2. Fish J, Moore RM. Ectopic thyroid tissue and ectopic thyroid carcinoma. Ann Surg 1963;157:212-22.

3. Larochelle D, Arcand P, Belzile M, Gagnon NB. Ectopic thyroid tissue-a review of the literature. J Otolaryngol 1979; 8:523-30.

4. Rogers WM, Kesten HD. Embryologic bases for thyroid tissues in the heart. Anat Rec 1962;142:323.

5. Randolph J, Grunt JA, Vawter GF. The medical and surgical aspects of intratracheal goiter. N Engl J Med 1963;268:45761 .

\section{HUGE THYMIC CYSTS}

Uğur Gönüllü, MD, Adem Güngör, MD, I̊smail Savaş, MD, Özlem Özdemir, MD, Gül Moğulkoç, MD, Doğanay Alper, MD, and Şinasi Yavuzer, MD, Ankara, Turkey

Thymic cysts are uncommon mediastinal lesions located in the anterior compartment in all age groups. They are usually asymptomatic and found incidentally on chest roentgenograms. ${ }^{1}$ Rarely the cysts cause symptoms, such as hoarseness or dyspnea, resulting from pressure on nearby organs. The cysts may be uniloculated or multiloculated, ranging in size from microscopic to enormous, almost filling an entire chest.

Five patients with thymic cyst were seen in our hospital and treated surgically (Table I). Most cysts were of moderate size, but one in a 24-year-old woman almost completely opacified the left side of the chest, measuring $30 \mathrm{~cm}$ in its greatest diameter (Fig. 1). In four patients, the

From the Departments of Respiratory Diseases and Thoracic Surgery, Medical School of Ankara University, Ankara, Turkey.

Received for publication April 20, 1995; accepted for publication Dec. 7, 1995.

Address for reprints: Uğur Gönüllü, MD, Özveren Sokak 26/1, Demirtepe Ankara, 06570 Turkey.

J Thorac Cardiovasc Surg 1996;112:835-6

Copyright (C) 1996 by Mosby-Year Book, Inc.

$0022-5223 / 96 \$ 5.00+0 \quad \mathbf{1 2 / 5 4 / 7 1 1 6 4}$ lesions could be readily excised through a thoracotomy incision; the fifth patient required median sternotomy. All patients did well in the postoperative period and were discharged from the hospital free of symptoms.

When a thymic cyst is located in the neck, a mass can be detected, which can cause dyspnea and hoarseness. Three of our patients had dyspnea or cough or both. The others were free of symptorns. These cysts may be uniloculated or multiloculated and of various sizes. To our knowledge, the largest thymic cyst previously reported was $18 \mathrm{~cm}$ in diameter and multiloculated. ${ }^{2}$ The cyst in our case 4 is the largest uniloculated cyst reported, measuring $17 \mathrm{~cm}$, and that in our case 5 is the largest multiloculated cyst $(30 \mathrm{~cm})$ reported (Table I).

On chest roentgenograms, thymic cysts look like smoothly contoured anterior mediastinal masses. A number of authors also have drawn attention to the usefulness of computed tomographic scans in evaluation of the thymus gland. ${ }^{3}$ We performed thoracic computed tomographic scans in most of our patients and the findings supported the diagnosis.

Reports of thymic cysts developing after radiotherapy have been reported. ${ }^{4}$ Neither of our patients had received radiotherapy. Thymic cysts can also form after thoracic

Table I. Features of cases of thymic cysts

\begin{tabular}{|c|c|c|c|c|}
\hline $\begin{array}{l}\text { Case No. } \\
\text { (age, sex) }\end{array}$ & Thyroid & Chest $x$-ray film & Size $(\mathrm{cm})$ & Operation \\
\hline $1(27, M)$ & Diffuse palpable & Superior mediastinal widening & 11 by 7 by 5 & Median sternotomy \\
\hline $2(38, F)$ & Nodule in isthmus & Widened upper and medial mediastinum & 8 by 5 by 4 & Thoracotomy \\
\hline $3(39, \mathrm{M})$ & Nonpalpable & Right hilar lesion & 8 by 5 & Thoracotomy \\
\hline $4(32, F)$ & Diffuse palpable & $\begin{array}{l}\text { Homogeneous lesion extending from sec- } \\
\text { ond intercostal space to base in left } \\
\text { hemithorax with calcified borders }\end{array}$ & 17 by 10 by 8 & Thoracotomy \\
\hline $5(24, F)$ & Nonpalpable & $\begin{array}{l}\text { Well-circumscribed lesion filling left } \\
\text { hemithorax with deplacement of } \\
\text { mediastinum to the right }\end{array}$ & 30 by 25 by 20 & Thoracotomy \\
\hline
\end{tabular}

